\title{
Leadership Education Is Not Enough: Advancing an Integrated Model of Student-Athlete Development
}

\author{
Donald G. DiPaolo, Ph.D. \\ University of Detroit Mercy \\ Detroit, MI
}

\begin{abstract}
This article advocates a new approach to how we work with the millions of studentathletes in schools by examining a more holistic model of player development. Rather than assisting students in separate silos and initiatives, the argument is made for integrating the areas of leadership education, performance psychology, and personal development into one unified model. Suggestions are made for how appropriate assessment and learning designs could lead to enhanced player and team success. The significant implications for athletes, coaches, parents, athletic department personnel, and schools is explored as well as the possibility for redefining what it means to participate in sport.
\end{abstract}

\section{Issue for Exploration}

Those of us who care deeply about leadership education have watched the transformative power it can have in the lives of our student-athletes. But what happens when leadership education isn't enough? What do we do when leadership skills are not accompanied by performance success and overall personal well-being? In spite of all our good efforts, what if we are missing some big pieces of the puzzle by not intentionally expanding our view of leadership education to include complimentary and necessary fields of study?

There are over 480,000 students playing intercollegiate athletics in the United States and an additional 2,000,000 playing college club sports (NCAA, n.d.-b; Pennington, 2008). At the high school level, participation has been growing steadily for 26 years and now is nearing $8,000,000$ students (2015). Student-athletes are a population that we reach with classes, retreats, presentations, seminars and a host of other curricular and cocurricular initiatives. Naturally drawn to the concepts of leadership due to the dynamics of competition, team membership, and sport, we have made great inroads in reaching athletes with our passion for leadership education. These students have found us and we have found them.

Having spent the past decade working with high school and college athletic teams, in most cases being deeply embedded in the program as a consultant, it became apparent to me that teaching leadership skills to athletes, while gratifying, wasn't enough. The problem is that you can possess strong leadership skills, but still fall apart or "choke" under the pressure of competition. Relatedly, you may have great leadership skills, but that does not guarantee you will be self-reflective, wise, and make healthy choices in your relationships. Really frustrated 
student-athletes with strong leadership skills can still make awfully bad decisions in their personal life and it can cost them dearly.

Despite my best efforts, it became clear to me that there were large missing pieces in my idea of what makes athletes and teams successful. I was failing them. I had to accept that leadership education was not enough - that it must intentionally be paired with components of performance psychology and personal development if our student-athletes are going to thrive. The problem is that when I began my investigation into a helpful and holistic model of player development, none was found.

\section{Review of Related Literature}

There are some general models for the development of student athletes, but a careful review would suggest they do not reflect the sense of cura personalis, or care for the whole person, to which most student life professionals, coaches, parents, teachers, professors, counselors, and others aspire. What I found was rich research and practice, but the genres in the literature were not connecting.

General Ideas and Models for Student-Athlete Development. Researchers have advanced notions about the overall well-being and experiences of student-athletes and have reminded us that we should be athlete-centered (Nelson, Cushion, Potrac, \& Groom, 2014). There is recognition of the need to develop student-athletes, both on the personal and performance side (Maher, 2007). Related to this, there have been calls for national data on what they truly are experiencing (Gayles, 2009) and for synthesizing the many areas of research of the student-athlete experience (Navarro \& Malvaso, 2015). Others have noted that, especially for high-profile athletes or sports, there is much going on "inside the bubble" that we ought to be investigating more closely (Menke, 2016). There are also reminders of the need to provide a wide range of support and services to athletes both in and out of the classroom (Carodine, Almond, \& Gratto, 2001).

The literature offers significant information about youth development in sport, the role of parents, and how young people perceive that role (Leff \& Hoyle, 1995; Wuerth, Lee, \& Alfermann, 2004). Many have noted that parents, though perhaps well-intended, often are not helping (Camiré, 2014). A simple observation at any local youth competition helps make that point and is a common frustration of coaches at all amateur levels. The models that do exist for developing young athletes tend to be focused on just talent and skill development at specific ages rather than something more holistic (Bailey \& Morley, 2006; Burgess \& Naughton, 2010). At the other end of the spectrum is a body of research looking at the difficult transition that athletes face when they end their athletic careers (Wylleman \& Lavalle).

A critical and important voice emerging in the research is the need for an integrated framework of athlete development (Gulbin, Croser, Morley, \& Weissensteiner, 2013). Thus far, the field of student-athlete development tends to exist in silos-focusing on narrow parts of the overall sports experience. 
Leadership Models. There is significant research about leadership behavior in sports, in general, and the effective leadership development of students in college organizations (Ewing \& Bruce, 2009; Smoll \& Smith, 1989). More specifically, some of this looks at leadership behavior by coaches and captains and how that impacts group cohesion on teams (Gardner \& Bostro, 1997; Gould \& Voelker, 2010; Murray, 2006). This investigation into leadership development of student-athletes includes inquiry related to the various levels of the sport that is played, such as middle school, high school, and beyond (Anderson, 2012). The critical link between leadership behavior and how that impacts role clarity among the various players in team sports has also been explored (Beauchamp, Bray, Eys, \& Carron, 2005).

The National Collegiate Athletic Association (NCAA) is very much involved in leadership development as thousands of student athletes participate in their leadership development academy and programming (NCAA, n.d.-c). In addition, they sponsor an Athlete Development Professional Certificate that is certificate designed to help coaches become more effective in their leadership development work with student-athletes (NCAA, n.d.-a).

Personal Development and Life Skills. The notion that participation in athletics contributes to the personal development of student-athletes is widely accepted (Danish, Petitpas, $\&$ Hale, 1993). Athletic organizations are well aware of their responsibility and capacity to contribute to life skill development of athletes (Andrassy, Svensson, Bruening, Huml, \& Chung, 2014). The NCAA has an entire Life Skills initiative dedicated to this effort (NCAA, n.d.-d). In addition, a line of research has looked at the effects of competition on character (Stoll, 2012). In an era when daily headlines broadcast the poor choices and embarrassing decisions that studentathletes make, coaches, parents, and school administrators have begun to question the very notion that personal development in sport is even possible (Black, 2010). In terms of academic success, there is considerable attention on models and notions of increasing the academic growth of student athletes (Comeaux \& Harrison, 2011).

At the high school level, there has been research on how coaches can successfully develop transferable life and interpersonal skills in their athletes (Camiré, Trudel, \& Forneris, 2012). The importance of these skills and how they related to the unique challenges and cultural context of urban youth have also been investigated (Petitpas, Van Raalte, Cornelius, \& Presbrey, 2004).

Performance Psychology, Counseling, and Wellness. The increasingly common stories of depression, addiction, and suicide among professional and amateur athletes is deeply troubling. There is ever-growing attention being paid to enhancing the personal development of student-athletes via provision of counseling and promoting mental health through coaching and competitive sports (Bell, 1997; Chartrand \& Lent, 1987). Related to this, some have reminded us of the need to provide comprehensive mental health services to student-athletes and encouraged to use an integrated outreach wellness model (Beauchemin, 2014; Etzel, 2006). What is abundantly clear to those who work with athletes is that it is immensely frustrating for everyone when one's potential isn't converted into performance (Freedberg, 1997).

There has been extensive effort to trace the origins of performance psychology practices and models in athletics (Bruner, Erickson, McFadden, \& Côté, 2009). A growing consensus is 
emerging that this field has critical knowledge to offer athletes, coaches, and parents and that it is mostly untapped at this point. It is not hard to find mass market books and scholarly articles galore talking about the mental aspect of sports. Some have explored developing mental toughness in general while others have focused on college athletes (Butt, Weinberg, \& Culp, 2010; Mack \& Casstevens, 2002; Selk, 2008). Finding a way to integrate sports psychology into teams of all kinds is an important factor that carries with it ethical, economic, interpersonal, and organizational challenges (McCalla \& Fitzpatrick, 2016). As with the components noted above, there are hopeful and important calls for an integrated approach to mental skills training for student-athletes (Lubbers, 2001). The is a growing conversation in the sports world among those who believe performance psychology is the missing piece (Williams, 2005).

\section{More Integrated Graphic Models of Student-Athlete and Player Development.} There are some interesting and more integrated models of player development from around the world, including World Rugby (Ireland), Manchester Junior Football (England), Canadian Lacrosse, and Hockey Canada ("Hockey Canada long term player development plan," 2013; "Long-term athlete development for Canadian lacrosse," n.d.; "Long-term player devleopment," n.d.; "Player Development," n.d.; "Player Development Programme,"). These begin to show an appreciation of the holistic nature of technical, physical, social, and psychological aspects of athletic performance. The problem with these is that there is mention of the holistic nature but no specific student learning outcomes or curriculum to teach them.

In the United States there are two models of note that approach an integrated perspective. First, there is the USA Hockey plan for long-term athlete development (Martel, 2015). Secondly, the most thorough and comprehensive effort appears to be the US Youth Soccer Player Development Model ("US Youth Soccer Player Development Model," 2012). These both trace player development stages over time and introduce skills that are age and developmentally appropriate, with mentions of psychological and team skills growth. The specific curriculum and learning outcomes related to the human skills are not clear, but their framework for the ongoing professional development of coaches is a possible vehicle for inclusion.

\section{A Possible Pedagogy}

Components of the Model. A more integrated approach to working with studentathletes and the elements that may be included are displayed in Figure 1.

Personal development. The first component involves the kinds of things that are essential to a well-adjusted student-athletes:

- Building self-confidence as a person and player,

- Creating strong relationships, and

- Practicing effective communication skills.

Building Self-Confidence as a Person and Player involves levels of self-awareness, the practice of self-reflection, the accuracy of self-perceptions, awareness and demonstration of personal values, and the degree to which the athlete seeks out feedback from others. 
Creating Strong relationships deals with emotional intelligence, choices in relationships with others, level of investment into relationships with others, the ability to forgive, and one's trustworthiness.

Practicing Effective Communications skills explores the degree to which the athlete shares thoughts and feelings, the practice of "being there" personally and emotionally for others on the team, the ability to engage in difficult but important conversations, the capacity to be fully present when listening, and one's level of open-mindedness.

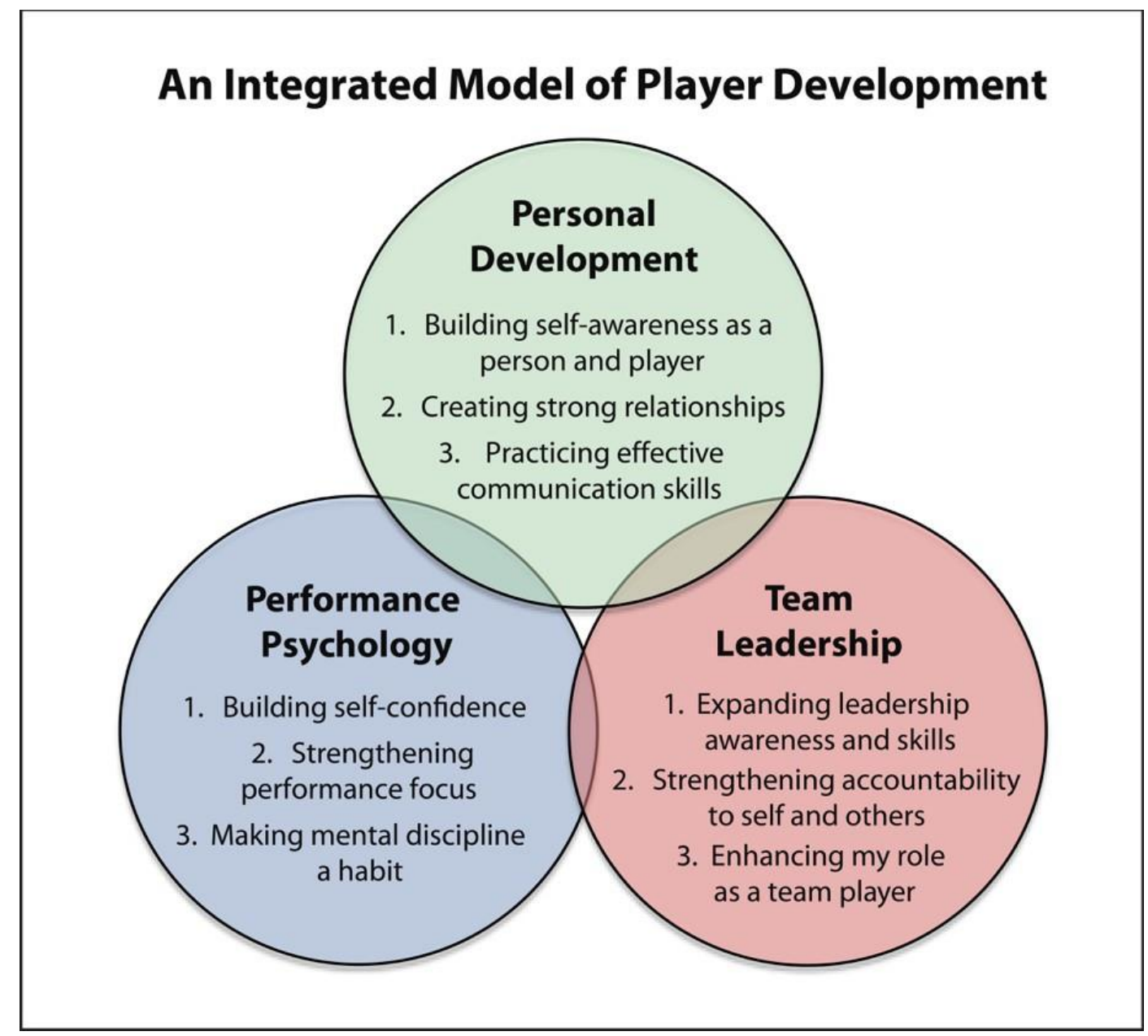

Figure 1. An integrated model of player development.

Performance psychology. The second sphere involves the importance of sports psychology in performance and player development. The three areas of performance psychology are:

- Building self-confidence,

- Strengthening performance focus, and

- Making mental discipline a habit.

Building Self-Confidence involves the practice of letting go of mistakes, recognizing daily personal accomplishments, the ability to recognize things you have done right regardless of 
other mistakes, the ability to appreciate and evaluate personal success regardless of the performance of others, and one's reaction to personal criticism.

Strengthening Performance Focus deals with the ability to focus on controllable aspects of practice and competition, the ability to stay in the moment and be free from distraction, the habit of remembering to have fun during competition, the degree to which the athlete dwells on mistakes, and the amount the athlete worries about the evaluation of others during performance.

Making Mental Discipline a Habit involves maintaining a consistent mindset for all practices and competitions, the ability to play at one's highest level regardless of the pressure and intensity of the situation, the issue of complacency, consistent focus and effort regardless of the score, and the routine of self-monitoring energy during competition.

Team leadership. The third component involves leadership and membership skills on a team. In this model, team leadership is broken down into three areas:

- Expanding leadership awareness and skills,

- Strengthening accountability to self and others, and

- Enhancing my role as a team player.

Expanding Leadership Awareness and Skills explores self-identification as a leader, willingness to take on leadership roles, self-awareness of leadership strengths and weaknesses, ability to inspire others, and the practice of seeking feedback from others about leadership effectiveness.

Strengthening Accountability to Self and Others involves one's past history of holding others accountable, current willingness to hold others accountable for their actions that harm the team, the degree to which the athlete perceives accountability as a coach or captain responsibility, how past behavior shapes one's level of accountability to others, and the athlete's ability to admit mistakes.

Enhancing My Role as a Team Player looks at the practice of undercutting team leadership, one's habit of building unity on the team, the degree to which the athlete is engaged in celebrating the success of other people, the athlete's perceived level of selfishness, and the ability to know when and how to be a good follower.

Why The Interrelatedness Matters. The interrelatedness of this model is critical because my experience with high school, college, and professional athletes has shown that when a student-athlete is weak in one area of the model, there is tremendous vulnerability in all. As with a tripod, when one leg cracks the structure falls. The problem with our research, developmental models, and practice in the area of student-athlete development is that we tend to scaffold understanding within a particular area of experience and ignore the cross-pollination that happens in the real world of being an athlete. So much time and money is spent developing athletes, but no one has pulled together the separate approaches. Some examples of why this is critical to address follow. 
The Athlete with Strong Leadership Skills — it is Not Enough. If you have an athlete who possesses strong team leadership skills but consistently underperforms or "chokes" in competition, they will not be satisfied with their performance and it will impact how they are perceived by the coaches and team. Eventually, their ability to lead others will dwindle. This lack of performance can cause problems in their ability to cope, reduce their happiness, and can lead to self-destructive personal decisions.

If athletes have great leadership skills and is a high performer, but they ignore their personal development and don't really invest in relationships with others, their ability to lead will be limited and they may make personal choices that hurt their status on the team. Sport is filled with talented, charismatic student-athletes who are vulnerable because of the decisions they make in their personal life and relationships.

The Athlete with Strong Performance Psychology Skills—it is Not Enough. During the course of developing our model we have experienced overwhelming evidence suggesting the need for development in performance psychology. Players, coaches, and parents are begging for help but most organizations don't have the resources, knowledge, or internal capacity for integrating this critical skill area into their programs.

For student-athletes who demonstrates strong performance skills, they often enjoy a heightened position on the team. Their talent often brings them attention, favor, and positional leadership status - such a being named captain. When this athlete makes poor or self-destructive personal decisions, it may impact their ability to lead and could even lead to team discipline or suspension. We are bombarded by examples of this daily in the media. Student-athletes who demonstrate strong performance but do not have strong team membership or leadership skills, will most likely become an isolated members of the team, often seen as selfish. They may lead the team, but in the wrong direction.

The Athlete with Strong Personal Development Skills - it is Not Enough. Coaches, parents, and teammates love the athlete who is unselfish, cares about others, and communicates well. However, being a "great kid" does not necessarily translate into a successful or pleasant athletic experience.

There are plenty of tremendous student-athletes who simply cannot perform well during competition, even when they possess the talent to do so. Teams and fans root hard for them, but sports can become incredibly frustrating and even brutal for such an athlete. For student-athletes who are competitors, it is not enough to be well-liked and nice-they want to excel. Athletes may not show their growing anger or frustration, but it can be a deeply troubling dynamic that goes to the very ego identity of the student. Relatedly, if student-athletes have strong personal development skills and do perform at a high level, but they are not good leaders or followers, team sports may often become an isolated experience for them. In addition, it is easy to misunderstand the motivations of this kind of teammate.

Theoretical Support for the Model. There is widespread agreement in pedagogical research that student learning is not one-dimensional and that it must be integrated to be effective (Iyer, 2015; Love \& Love, 1995). Across student development literature there are myriad 
reminders that we must take holistic approaches when we work with college students (Baxter Magolda, 2009).

I would argue that this is especially true for student-athletes because the nature of their experience is real-world and practice-based. It is also important to acknowledge approaches to athletics and coaching that stress complex learning theory and the holistic and often very-public context in which student-athletes operate (Light, Harvey, \& Mouchet, 2014). The nature of sport calls for theoretical approaches that demonstrate a respect for the multi-dimensional realities and pressures under which these students live.

\section{Future Directions and Possible Outcomes}

Assessment Tool. It is obvious, especially in the world of athletics where measurement is important, that some sort of assessment tool ought to be developed and employed. My colleague and I have created a 45 question Likert-type ratings scale for use with student-athletes that we are now piloting based on the model presented above in Figure 1.

The value of an integrated and holistic assessment tool is that it can be used to help individual student-athletes look at areas of their athletic development that may be strong and a source for success. It can also serve as an instrument to improve areas of relative weakness and assist in creating meaningful plans to help the student-athlete. For the coaching staff and team as a whole, the assessment tool may reveal trends in a team that could be useful as curricular plans are made for ongoing team development and improvement. Also, coaches can use the information revealed to make more strategic decisions regarding their own personal development, coaching style, and even the recruitment of future players and coaches.

A National Dialogue That Helps Student-Athletes. Regardless of the specific model, assessment tool, or delivery method, it is my hope that this article can help inspire a larger dialogue about how we can better serve student-athletes. The time has come to bring people together and reach across disciplines, job descriptions, and titles to rethink our approach to athletics. Coaches, student life professionals, leadership educators, athletic department personnel, professors, concerned parents, and local, national, and international organizations all have a huge stake in the outcome. There is the possibility for a meaningful and strategic summit that could be convened by interested parties in the NCAA, at the college level, or NFHC, at the high school level. An important ingredient to this gathering would be everyone's ability to suspend personal ego and inclination to be territorial and approach the concept with openness and a spirit of collaboration.

A Happier Athlete. The end game of this idea brief is that student-athletes may have a more enjoyable experience in sport and grow to become more highly functional human beings. What we as leadership educators, coaches, parents, and professors currently provide them lacks key integration or wholeness. As a result, overall player performance and satisfaction are negatively impacted. An integrated player development model, especially one that has widespread appeal, would focus our attentions in a way that has a better chance of meeting the needs and developing the full potential of the student athlete. So many people involved in the lives of student-athletes feel at cross-purposes with others, are frustrated with their inability to 
help young people succeed, and are searching for answers. If people and organizations that care about the growth of our athletes had a more integrated model, great synergies and efficiencies of effort could produce approaches that had a better chance of truly helping young people. Related to this, a model that has a means of assessment would help us get a better idea of how athletes are functioning in more integrated domains and, thus, could provide individual-specific strategies to help them be successful.

So much of what we do to assist athletes is rooted in "old-school" practices that are often borne out of outmoded clichés and are ineffective with the modern athlete (Elmore, 2015; Janssen, 2014). There is plenty of expertise in the field that could help us find a better way.

More Functional and Successful Teams. As we assist the individual athlete, we assist the team. Enhanced performance, leadership, and interpersonal skills are likely to increase the functioning and success of the team. When great amounts of energy are spent on personal and interpersonal dysfunction in team settings, athletes and coaches are often at odds with each other. This internal conflict can be a major distraction and can get in the way of skills development, performance, and even enjoyment of the sport.

Anyone that has played competitive sports can tell you that a functional team is a source of great pride, energy, and even love. A team experience that is bad can have a significant negative impact on the evolution and growth of the young person by hurting, rather than helping, self-esteem, self-efficacy, and overall psycho-social development.

More Effective Coaches. There can be immense pressure on coaches, especially if the sport is high profile or one's income is dependent on winning. Volunteer and professional coaches attempt to teach and mentor student-athletes, sometimes in very difficult settings. When things do not go well, coaches may have limited approaches, strategies, and "tricks" to remedy the situation. In the best case scenario, coaches reach out for help and adapt. In the worst case scenario, a coach can do great damage to the athlete.

Great benefit could be experienced by all if coaches were given more comprehensive tools, training, and assistance in meeting the varied needs and significant challenges of today's student athlete. Of course, this would come with the imperative that we redefine what it means to practice. Overwhelming hours are invested in weight rooms, film rooms, and fields of play. The more effective coach would recognize that time and focus must be spent practicing skills and habits previously ignored - human and interpersonal skills that are critical to overall player success.

Schools and Organizations That Can Be More Proud. The failures of our athletes are well-documented and often widely publicized, often bringing great embarrassment to the school or organization, in addition to the athletes themselves. Too often our interventions are reactive rather than proactive. Much time, money, and attention is paid to fixing problems in sports after the problem has become all too apparent. It seems obvious that the preferred approach ought to be early investment in player development that lessens the chance of the problems arising in the first place. Investing in an intentional player development model that is more integrated and 
effective has the chance of producing the kinds of young men and women that edify schools and organizations and are a source of great pride.

In many cases, organizations make millions of dollars and garner immense marketing value off of the efforts of student-athletes. I believe we have a moral and ethical obligation to seek better ways of supporting their growth and maturation.

\section{References}

Anderson, M. D. (2012). The leader development of college students who participate in different levels of sport. (Ph.D.), The Ohio State University, Columbus, $\mathrm{OH}$.

Andrassy, E. J., Svensson, P., Bruening, J., Huml, M. R., \& Chung, M. (2014). The role of organizational capacity in student-athlete development. Journal of Intercollegiate Sport, $7(2), 218-244$.

Bailey, R., \& Morley, D. (2006). Towards a model of talent development in physical education. Sport, Education and Society, 11(3), 211-230. doi:10.1080/13573320600813366

Baxter Magolda, M. B. (2009). The activity of meaning making: A holistic perspective on college student development. Journal of College Student Development, 50(6), 621-639.

Beauchamp, M. R., Bray, S. R., Eys, M. A., \& Carron, A. V. (2005). Leadership behaviors and multidimensional role ambiguity perceptions in team sports. Small Group Research, 36(1), 5-20. doi:10.1177/1046496404266684

Beauchemin, J. (2014). College student-athlete wellness: An integrative outreach model. College Student Journal, 48(2), 268-280.

Bell, C. C. (1997). Promotion of mental health through coaching competitive sports. Journal of the National Medical Association, 89(8), 517-520.

Black, D. R. (2010). The ambiguities of development: Implications for 'development through sport'. Sport in Society, 13(1), 121. doi:10.1080/17430430903377938

Bruner, M. W., Erickson, K., McFadden, K., \& Côté, J. (2009). Tracing the origins of athlete development models in sport: A citation path analysis. International Journal of Sport and Excercise Psychology, 2(1), 23-37.

Burgess, D. J., \& Naughton, G. A. (2010). Talent development in adolescent team sports: A review. International Journal of Sports Physiology Performance, 5(1), 103-116.

Butt, J., Weinberg, R., \& Culp, B. (2010). Exploring mental toughness in NCAA athletes. Journal of Intercollegiate Sport, 3(2), 316-332.

Camiré, M. (2014). Youth development in North American high school sport: Review and recommendations. Quest, 66(4), 495-511. doi:doi: 10.1080/00336297.2014.952448 
Camiré, M., Trudel, P., \& Forneris, T. (2012). Coaching and transferring life skills: Philosophies and strategies used by model high school coaches. The Sport Psychologist, 26(2), 243260.

Carodine, K., Almond, K. F., \& Gratto, K. K. (2001). College student athlete success both in and out of the classroom. New Directions for Student Services, 2001(93), 19-33.

doi:10.1002/ss.2

Chartrand, J. M., \& Lent, R. W. (1987). Sports counseling: Enhancing the development of the student-athlete. Journal of Counseling \& Development, 66(4), 164-167.

doi:10.1002/j.1556-6676.1987.tb00837.x

Comeaux, E., \& Harrison, C. K. (2011). A conceptual model of academic success for studentathletes. Educational Researcher, 40(5), 235-245. doi:10.3102/0013189x11415260

Danish, S. J., Petitpas, A. J., \& Hale, B. D. (1993). Life development intervention for athletes: Life kkills through sports. The Counseling Psychologist, 21(3), 352-385.

doi:10.1177/0011000093213002

Elmore, T. (2015). A model for coaches to connect with Millenials. Retrieved from http://growingleaders.com/blog/a-model-for-coaches-to-connect-with-millennials/

Etzel, E. F. (2006). Understanding and promoting college student-athlete health: Essential issues for student affairs professionals. NASPA Journal, 43(3), 518-546. doi:doi: 10.2202/19496605.1682

Ewing, J. C., \& Bruce, J. A. (2009). Effective leadership development for undergraduates: How important is active participation in collegiate organizations? Journal of Leadership Education, 7(3), 11-132.

Freedberg, E. J. (1997). Activation: The Core Competency. Toronto, ON: Harper Collins.

Gardner, D. E., \& Bostro, A. (1997). The relationship between leadership behaviors and group cohesion in team sports. The Journal of Psychology, 131(2), 196-210. doi:doi: 10.1080/00223989709601964

Gayles, J. G. (2009). The student athlete experience. New Directions for Institutional Research, 2009(144), 33-41. doi:10.1002/ir.311

Gould, D., \& Voelker, D. K. (2010). Youth sport leadership development: Leveraging the sports captaincy experience. Journal of Sport Psychology in Action, 1(1), 1-14. doi:10.1080/21520704.2010.497695

Gulbin, J. P., Croser, M. J., Morley, E. J., \& Weissensteiner, J. (2013). An integrated framework for the optimisation of sport and athlete development: A practitioner approach. Journal of Sports Sciences, 31(12), 1319-1331. doi:10.1080/02640414.2013.781661 
Hockey Canada long term player development plan. (2013). Retrieved from https://www.hockeycanada.ca/en-ca/Hockey-Programs

Iyer, R. B. (2015). Blending east and west for holistic education. Educational Research and Reviews, 10(3), 244-248.

Janssen, J. (2014). Seven keys to coaching today's millenial generation athlete. Championship Coaches Network. Retrieved from http://www.championshipcoachesnetwork.com/public/378.cfm

Leff, S. S., \& Hoyle, R. H. (1995). Young athletes' perceptions of parental support and pressure. Journal of Youth and Adolescence, 24(2), 187-203.

Light, R. L., Harvey, S., \& Mouchet, A. (2014). Improving "at-action" decision-making in team sports through a holistic coaching approach. Sport, Education and Society, 19(3), 258275.

Long-term athlete development for Canadian lacrosse. (n.d.). Retrieved from https://secure.pointstreaksites.com/files/uploaded_documents/2253/Overview-EN.pdf

Long-term player devleopment. (n.d.). Retrieved from http://www.irbrugbyready.com/index.php?section=56\&language=en

Love, P. G., \& Love, A. G. (1995). Enhancing Student Learning: Intellectual, Social, and Emotional Integration. ASHE-ERIC Higher Education Report No. 4. Washington, D.C.: ERIC Publications.

Lubbers, P. (2001). An integrated approach to mental skills training. USTA Newsletter for Tennis Coaches. Retrieved from http://s3.amazonaws.com/ustaassets/assets/1/usta_import/usta/dps/doc_437_43.pdf

Mack, G., \& Casstevens, D. (2002). Mind Gym: An Athlete's Guide to Perforamnce Excellence. New York, MY: McGraw-Hill.

Maher, C. A. (2007). Clinical sport psychology case conference response paper 2--case study commentary: Addressing the personal and performance needs of a collegiate studentathlete. Journal of Clinical Sport Psychology, 1(2), 190-197.

Martel, K. (2015). USA Hockey's American Development Model: Changing the coaching and player development program. International Sport Coaching Journal, 2(1), 39-49.

McCalla, T., \& Fitzpatrick, S. (2016). Integrating sport psychology within a high-performance team: Potential stakeholders, micropolitics, and culture. Journal of Sport Psychology in Action, 7(1), 33-42.

Menke, D. J. (2016). Inside the bubble: College experiences of student-athletes in revenueproducing sports. Journal for the Study of Sports and Athletes in Education, 10(1), 16-32. doi:10.1080/19357397.2016.1160695 
Murray, N. P. (2006). The differential effect of team cohesion and leadership gehavior in high school sports. Individual Differences Research, 4(4).

Navarro, K., \& Malvaso, S. (2015). Synthesizing research on the contemporary student-athlete experience: Implimcations and recommendations for NCAA student-athlete development programming. Journal of College and Character, 16(4), 263-269. doi:doi: 10.1080/2194587X.2015.1091358

NCAA. (n.d.-a). Athletic Devolopment Professional Certificate Program. Retrieved from http://www.ncaa.org/about/resources/leadership-development/athlete-developmentprofessional-certification-program

NCAA. (n.d.-b). Current Student-Athletes. Retrieved from http://www.ncaa.org/studentathletes/current

NCAA. (n.d.-c). Leadership Development: College Athlete. Retrieved from http://www.ncaa.org/about/resources/leadership-development/college-athletes

NCAA. (n.d.-d). Life Skills. Retrieved from http://www.ncaa.org/about/resources/leadershipdevelopment/life-skills

Nelson, L., Cushion, C. J., Potrac, P., \& Groom, R. (2014). Carl Rogers, learning and educational practice: Critical considerations and applications in sports coaching. Sport, Education and Society, 19(5), 513-531. doi:10.1080/13573322.2012.689256

NFSHSA. (2015). High School Sports Participation Increases for 26th Consecutive Year. Retrieved from https://www.nfhs.org/articles/high-school-sports-participation-increasesfor-26th-consecutive-year/

Pennington, B. (2008, December 1). Rise of College Club Teams Creates a Whole New Level of Success. The New York Times. Retrieved from http://www.nytimes.com/2008/12/02/sports/02club.html?_r=0

Petitpas, A. J., Van Raalte, J. L., Cornelius, A. E., \& Presbrey, J. (2004). A life skills development program for high school student-athletes. The Journal of Primary Prevention, 24(3), 325-334.

Player Development. (n.d.). Retrieved from http://www.respectleague.com/

Player Development Programme. (n.d.). Retrieved from http://www.elite-preparationcentre.co.uk/

Selk, J. (2008). 10-Minute Toughness: The Mental Training Program for Winning Before the Game Begins. New York, NY.

Smoll, F. L., \& Smith, R. E. (1989). Leadership behaviors in sport: A theoretical model and research paradigm. Journal of Applied Social Psychology, 19(18), 1522-1551. doi:10.1111/j.1559-1816.1989.tb01462.x 
Stoll, S. K. (2012). The effects of athletic competition on character development in college student athletes. Journal of College and Character, 13(4). doi:doi: 10.1515/jcc-20121939

US Youth Soccer Player Development Model. (2012). Retrieved from http://www.usyouthsoccer.org/assets/1/3/US_Youth_Soccer_Player_Development_Mode 1.pdf

Williams, K. (2005). Sports psychologist: The missing piece? Retrieved from http://www.socawarriors.net/forum/index.php?topic=13035.msg20787 - msg20787

Wuerth, S., Lee, M. J., \& Alfermann, D. (2004). Parental involvement and athletes' career in youth sport. Psychology of Sport and Exercise, 5(1), 21-33.

Wylleman, P., \& Lavalle, D. A developmental perspective on transitions faced by athletes. In M. R. Weiss (Ed.), Development sport and exercise psychology: A lifespan perspective (pp. 503-524).

\section{Author Biography}

Donald G. DiPaolo, Ph.D., is an associate professor at the University of Detroit Mercy and can be reached at don.dipaolo@udmercy.edu. He is a leading, national voice in student leadership development and has presented to tens of thousands of college students across the United States and Canada. 